\title{
Pengaruh Motivasi Belajar Dan Komitmen Organisasional Terhadap Prestasi Mahasiswa Studi Kasus Pada Mahasiswa Universitas Raharja
}

\author{
Rizka Mukhlisiah ${ }^{1}$, Muhammad Acla Alamsyah Nurdin Hamzah ${ }^{2}$, Mahendra \\ Setiawan $^{3}$ \\ ${ }^{1}$ Program Studi Akuntansi Universitas Raharja, ${ }^{2,3}$ Program Studi Teknik Informatika Universitas \\ raharja \\ Email: ${ }^{1}$ rizka.mukhlisiah@ raharja.info, ${ }^{* 2}$ acla@ raharja.info, ${ }^{3}$ mahendra.setiawan@ raharja.info
}

\begin{abstract}
Student achievement is one of the main factors that need to be considered on campus to achieve the university's goals. Students are an important value owned by the university where all activities on campus can be carried out with the presence of students. One way that students are encouraged to study earnestly so that they can achieve optimal achievement, companies need to pay attention to learning motivation and organizational commitment. The purpose of this study is to find out and explain the influence of learning motivation and organizational commitment to student achievement in university students. The type of research used is survey research through google online form that is explanatory research. The number of samples in this study was 9 students. From the results of statistical analysis that learning motivation has a significant effect on student achievement variables, as well as learning motivation variables and organizational commitment variables have a significant effect on student achievement variables.
\end{abstract}

Keywords: Learning Motivation, Organizational Commitment, Achievement, Students

Abstrak

Prestasi mahasiswa merupakan salah satu faktor utama yang perlu diperhatikan pada kampus untuk mencapai tujuan universitas. mahasiswa merupakan nilai penting yang dimiliki oleh universitas dimana segala aktivitas dalam kampus dapat dilaksanakan dengan adanya mahasiswa. Salah satu cara agar mahasiswa terdorong untuk belajar dengan sungguh-sungguh sehingga dapat mencapai prestasi yang optimal, perusahaan perlu memperhatikan motivasi belajar dan komitmen organisasional. Tujuan penelitian ini untuk mengetahui dan menjelaskan pengaruh motivasi belajar dan komitmen organisasional terhadap prestasi mahasiswa pada mahasiswa universitas raharja. Jenis penelitian yang digunakan adalah penelitian survei melalui google form online yang bersifat penjelasan (explanatory research). Jumlah sampel pada penelitian ini sebanyak 9 mahasiswa. Dari hasil analisis statistik bahwa motivasi belajar berpengaruh signifikan terhadap variabel prestasi mahasiswa, variabel komitmen organisasional berpengaruh signifikan terhadap variabel prestasi mahasiswa, variabel komitmen organisasional berpengaruh signifikan terhadap variabel prestasi mahasiswa, serta variabel motivasi belajar dan variabel komitmen organisasional berpengaruh signifikan terhadap variabel prestasi mahasiswa.

Kata kunci: Motivasi Belajar, Komitmen Organisasional, Prestasi, Mahasiswa

\section{Pendahuluan}

Pada tahun 2020, Bangsa Indonesia dan bangsa di negara-negara lain sedang dilanda pandemi Covid-19. Kondisi ini memberikan tantangan dan peluang untuk kita bangkit serta keluar dari rutinitas yang ada. Berdasarkan kebijakan pemerintah tentang bekerja, belajar, dan 
ibadah dari rumah menjadikan momentum yang baik untuk menciptakan kreativitas dan memanfaatkan teknologi sesuai dengan eranya. Berdasarkan surat Edaran Nomor 4 Tahun 2020 tentang Pelaksanaan Kebijakan Pendidikan dalam masa pandemi Covid-19, kemendikbud menghimbau agar semua lembaga pendidikan tidak melakukan proses belajar mengajar secara langsung atau tatap muka, melainkan harus dilakukan secara tidak langsung atau jarak jauh (daring) (Kemdikbud, 2020).

Universitas Raharja Tangerang secara sigap menanggapi kondisi ini dengan memberlakukan pembelajaran daring ini merupakan pembelajaran online yang dirancang sedemikian rupa secara kreatif agar menarik. Sistem Pembelajaran daring (SPADA) merupakan Learning Management System (LMS) yang digunkana Universitas Raharja, Perkuliahan daring yang diterapkan selama pandemik COVID-19 yakni synchronous, asynchronous dan gabung synchronous-asynchronous.

Dengan motivasi belajar yang tinggi diharapkan mahasiswa memperoleh hasil belajar yang baik. menurut Dimyati dan Mudjiono (2013) hasil belajar merupakan kemampuan seseorang yang dimiliki setelah menempuh pembelajaran. dengan kata lain hasil belajar merupakan pencapaian yang dimiliki oleh seseorang setelah melakukan proses pembelajaran.

Proses pembelajaran adalah merupakan ciri khas dalam suatu lingkungan sekolah. Dengan demikian aktivitas belajar adalah merupakan suatu aktivitas utama yang sedang menjalani pendidikan pada lembaga pendidikan. Hal ini dimaksudkan agar peserta didik dapat memiliki kesiapan yang cukup untuk melanjutkan pendidikan yang lebih tinggi maupun untuk memasuki lapangan kerja yang dalam masyarakat. Berkaitan dengan hal tersebut maka semua fasilitas, kondisi, proses kegiatan dan kebijakan yang ada pada suatu lembaga pendidikan semuanya bermuara pada penciptaan kegiatan belajar yang maksimal pada peserta didik. Kondisi ini diharapkan dapat menghasilkan output yang memiliki kompetensi yang dapat diandalkan.

Pengertian belajar menurut Gagne dan Briggs(dalam M.Djauhar Siddiq, dkk. 2008; 1.4) bahwa "belajar adalah suatu proses di mana suatu organisme berubah perilakunya sebagai akibat pengalaman". Winataputra dkk, 1997, 2.3 mendefinisikan belajar adalah "suatu proses dimana suatu organisme berubah perilakunya sebagai akibat pengalaman". Winkel (1996:53) mengatakan bahwa "belajar adalah suatu aktivitas mental/psikis yang berlangsung dalam interaksi aktif dengan lingkungannya, yang menghasilkan perubahan-perubahan, pengetahuan, pemahaman, keterampilan dan nilai sikap, serta perubahan itu bersifat secara relatif konstan dan tetap". Sedangkan yang dimaksud motivasi belajar adalah keinginan yang mengaktifkan, menggerakkan, menyalurkan dan mengarahkan sikap dan perilaku individu sebelum dan sesudah dia belajar mengenai suatu hal. Belajar dapat berasal dari pengalaman, bacaan/pengetahuan, pengamatan, aktivitas, fisik dan yang lainnya. Untuk membentuk individu dengan karakter dan pengetahuan yang baik maka diperlukan proses pembelajaran yang baik dan mengarah kepada hal-hal yang positif.

Secara umum, belajar adalah suatu proses atau usaha yang dilakukan oleh setiap individu untuk mendapatkan suatu perubahan di dalam kehidupannya baik tingkah laku, pengetahuan, sikap, keterampilan, pola atau daya pikir, nilai kehidupan, dan berbagai kemampuan lainnya yang diperlukan didalam kehidupan. Belajar sudah seharusnya mengarah kepada hal-hal yang positif dan bersifat membangun. Setiap individu dapat belajar dari lingkungan sekitarnya seperti di sekolah, di kampus, lingkungan pergaulan/masyarakat, laboratorium, museum dan yang lainnya.

Belajar mandiri merupakan salah satu kemampuan yang harus dimiliki oleh mahasiswa. Definisi belajar mandiri bukan berarti belajar sendiri, yaitu hanya memegang setumpuk buku yang coba dibaca semua dan diselesaikan sendiri. Kata kunci dari belajar mandiri adalah "inisiatif sendiri". Belajar mandiri berarti belajar secara berinisiatif, dengan ataupun tanpa bantuan orang lain di dalam belajar.

Pembelajaran merupakan proses yang sangat penting dari pendidikan. Pendidikan merupakan sebuah proses pembelajaran dari pengetahuan, keterampilan, sikap dan perilaku sosial, dimana dalam menjalani proses tersebut harus melewati tahapan yang telah dibuat untuk tercapainya sebuah tujuan (Fenty, 2010). Pendidikan saat ini tengah mengalami tantangan 
sebagai dampak mewabahnya virus Covid-19 dengan mengeluarkan kebijakan agar seluruh warga masyarakat melakukan social distancing atau menjaga jarak. Salah satu instruksi pemerintah tentang kegiatan yang dilakukan di rumah adalah kegiatan belajar. Belajar tidak boleh berhenti. Kegiatan belajar mengajar dipindahkan di rumah, tetapi harus dikendalikan oleh guru atau dosen dan orang tua, dengan menggunakan pembelajaran jarak jauh, (Anisa, Zaharah, \& Galia, 2020).

Permasalahan mengenai prestasi belajar mahasiswa saat ini masih tetap menjadi pusat perhatian bagi sebuah universitas/perusahaan untuk dapat bertahan di era globalisasi yang diiringi dengan tingkat persaingan yang semakin ketat. Prestasi belajar mahasiswa mempunyai peranan yang penting dalam setiap kegiatan universitas/perusahaan, karena Prestasi belajar mahasiswa berfungsi sebagai pelaksana kegiatan universitas. Hal ini menunjukkan bahwa manajemen sumber daya manusia merupakan salah satu kunci pokok di dalam universitas yang harus diperhatikan dengan segala kebutuhannya.

Manusia dalam suatu organisasi atau perusahaan mempunyai kedudukan yang sangat strategis karena manusia bisa mengetahui input input yang perlu diambil dari lingkungan, misalnya kondisi lingkungan belajar, pasangan belajar, dan fasilitas belajar. Melalui kedudukan tersebut manusia mampu menangkap dan mengelola input-input untuk selanjutnya diolah menjadi output-output yang memenuhi publik, misalnya informasi -

informasi belajar yang dapat digunakan dan diserap untuk kemudian dijadikan bekal mahasiswa dalam meningkatkan prestasinya. Dengan kemampuan ini, maka manusia menjadi penggerak dan penentu jalannya organisasi.

Memasuki era perdagangan bebas yang semakin kompetitif, setiap organisasi atau badan usaha baik domestik maupun multinasional memiliki berbagai bidang permasalahan yang harus diatasi, khususnya yang berkaitan dengan manajemen Prestasi belajar mahasiswa. Setiap organisasi atau badan usaha dituntut untuk dapat mengoptimalkan Prestasi belajar mahasiswa dan mengelola Prestasi belajar mahasiswa yang dimiliki. Pengelolaan Prestasi belajar mahasiswa tidak lepas dari faktor mahasiswa yang diharapkan dapat berprestasi sebaik mungkin demi mencapai tujuan organisasi atau badan usaha. mahasiswa merupakan aset utama organisasi mempunyai peran yang strategis didalam organisasi yaitu sebagai pemikir, perencana, dan pengendali aktivitas organisasi. Demi tercapainya tujuan organisasi, mahasiswa memerlukan motivasi agar bersedia belajar lebih rajin dan lebih serius. Melihat pentingnya mahasiswa dalam organisasi, maka diperlukan perhatian lebih terhadap tugas yang dibelajarkan mahasiswa sehingga tujuan organisasi tercapai. Dengan motivasi belajar yang tinggi, mahasiswa akan belajar dengan lebih giat dalam melaksanakan pembelajarannya. Sebaliknya dengan motivasi belajar yang rendah mahasiswa tidak mempunyai semangat belajar, mudah menyerah, dan kesulitan dalam menyelesaikan pembelajarannya. mahasiswa kurang memiliki informasi yang jelas apakah pembelajaran mereka memiliki dampak positif terhadap para penerima manfaatnya yaitu individu atau kelompok yang dilayani organisasi.

Oleh karenanya organisasi atau badan usaha harus lebih menekankan pada efektifitas dan efisiensi pengelolaan Prestasi belajar mahasiswa sehingga tujuan awal pendiriannya dapat tercapai. Penekanan tersebut tidak terkecuali pada badan usaha swasta maupun badan usaha milik pemerintah. Untuk menunjang hal tersebut dibutuhkan dukungan Prestasi belajar mahasiswa yang berkualitas, hal ini tercermin pada komitmen organisasional besar dan motivasi belajar memadai guna menciptakan prestasi yang baik. Universitas Raharja merupakan sebuah perguruan tinggi swasta di Tangerang, provinsi Banten, Indonesia, dengan konsentrasi pengajaran manajemen dan ilmu komputer. Semboyannya adalah "Get the Better Future by Computer Science".

Pada dasarnya, Universitas Raharja bukan saja mengharapkan mahasiswa yang mampu, cakap, dan terampil, tetapi yang terpenting mereka mau belajar giat dan berkeinginan untuk mencapai hasil belajar yang optimal. Kemampuan, kecakapan, dan keterampilan mahasiswa tidak ada artinya bagi perusahaan, jika mereka tidak mau belajar keras dengan mempergunakan kemampuan, kecakapan, dan keterampilan yang dimilikinya. Motivasi belajar dan komitmen organisasional penting karena dengan motivasi belajar dan komitmen 
organisasional yang memadai diharapkan setiap mahasiswa mau belajar keras dan antusias untuk mencapai produktivitas belajar yang tinggi dengan didukung oleh kemampuan yang mumpuni dan berkualitas.

Dalam rangka meningkatkan prestasi mahasiswa, Universitas Raharja juga harus dapat meningkatkan motivasi belajar para mahasiswa karena motivasi dapat mempengaruhi seseorang atau memberikan dorongan kepada seseorang untuk melakukan sesuatu. Faktorfaktor yang dapat meningkatkan motivasi belajar mahasiswa dapat bersifat individu seperti kebutuhan, sikap dan kemampuan, sedangkan yang bersifat organisasi meliputi pembayaran gaji, pengawasan, pujian, dan pembelajaran itu sendiri. Sehingga menjadi menarik bagi penulis untuk mengkaji bagaimana sebenarnya universitas/perusahaan berupaya meningkatkan motivasi belajar dan komitmen organisasional yang nantinya akan berdampak pada prestasi mahasiswa yang tentunya akan memberikan dampak positif bagi universitas.

Rumusan masalah dalam jurnal ini adalah Adakah pengaruh variabel motivasi belajar terhadap prestasi mahasiswa Universitas Raharja Tangerang? Adakah pengaruh variabel komitmen organisasional terhadap prestasi mahasiswa Universitas Raharja Tangerang? Adakah pengaruh simultan variabel motivasi belajar dan variabel komitmen organisasional terhadap prestasi mahasiswa Universitas Raharja Tangerang?

Tujuan Penelitian dalam Jurnal ini adalah Mengetahui dan menjelaskan pengaruh variabel motivasi belajar terhadap prestasi mahasiswa Universitas Raharja Tangerang. Mengetahui dan menjelaskan pengaruh variabel komitmen organisasional terhadap prestasi mahasiswa Universitas Raharja Tangerang. Mengetahui dan menjelaskan pengaruh simultan variabel motivasi belajar dan komitmen organisasional secara simultan terhadap prestasi mahasiswa Universitas Raharja Tangerang.

Kontribusi Penelitian dalam jurnal ini terdapat dua aspek. Aspek Akademis yaitu penelitian ini diharapkan dapat digunakan sebagai wacana dan bahan pertimbangan untuk penelitian selanjutnya dan menambah wawasan yang tertarik pada pengaruh motivasi belajar dan komitmen organisasional terhadap prestasi mahasiswa. Dan Aspek Praktis yaitu Penelitian ini diharapkan dapat dijadikan saran, masukan, atau bahan pertimbangan bagi perusahaan dalam membuat kebijakan dari hasil dari penelitian pengaruh motivasi belajar dan komitmen organisasional terhadap prestasi mahasiswa.

\section{Mahasiswa Berprestasi}

Departemen Pendidikan Nasional secara umum memberikan kriteria mengenai mahasiswa berprestasi, yaitu mahasiswa yang berhasil mencapai prestasi tinggi, baik akademik maupun non akademik, mampu berkomunikasi dengan bahasa Indonesia dan bahasa Inggris, bersikap positif, serta berjiwa Pancasila (Depdiknas, 2010). Secara khusus, kriteria mahasiswa berprestasi tersebut dapat dilihat dari: 1) IPK, 2) Karya tulis ilmiah, 3) aktif dalam kegiatan kurikuler, kokurikuler, dan ekstrakurikuler, 4) dapat berbahasa inggris dengan baik, serta 5) kepribadian.

Pemilihan mahasiswa berprestasi dilakukan secara berkala mulai dari tingkat jurusan, universitas, hingga nasional. Tujuan diadakannya pemilihan ini adalah untuk memberikan penghargaan kepada mahasiswa yang berhasil mencapai prestasi tinggi, memberikan motivasi kepada mahasiswa untuk melaksanakan kegiatan kurikuler, kokurikuler, dan ekstrakurikuler sebagai wahana mensinergikan hard skills dan soft skills mahasiswa, mendorong perguruan tinggi untuk mengembangkan iklim kehidupan kampus yang dapat memfasilitasi mahasiswa mencapai prestasi yang membanggakan secara berkesinambungan.

\section{Motivasi}

Istilah motivasi, seperti halnya emosi berasal dari bahasa Latin yang berarti "bergerak". Ilmu psikologi mempelajari motivasi dengan tujuan mempelajari penyebab atau alasan yang membuat individu melakukan apa yang dilakukan. Bagi para psikolog motivasi merujuk pada suatu proses dalam diri manusia atau hewan yang menyebabkan organisme tersebut bergerak menuju suatu tujuan atau bergerak menjauhi situasi yang tidak menyenangkan organisme 
tersebut bergerak menuju suatu tujuan atau bergerak menjauhi situasi yang tidak menyenangkan. Gage dan Berliner(1984) menyatakan bahwa istilah motivasi berkaitan dengan situasi dimana seseorang menjadi tergagah (aroused) dan kemudian mengarahkan perilaku tersebut pada suatu tujuan tertentu. Sementara Hardjana (1997) menjelaskan bahwa motivasi mendorong orang untuk bekerja mencapai sasaran dan tujuannya karena yakin dan sadar akan kebaikan, kepentingan, dan manfaatnya. Karena itu bisa juga dikatakan bahwa motivasi berarti membangkitkan motif, membangkitkan daya gerak, atau menggerakkan seseorang atau diri sendiri untuk berbuat sesuatu dalam rangka mencapai suatu keputusan atau tujuan.

\section{Motivasi Berprestasi}

Studi percobaan mengenai motivasi berprestasi bermula dari taksonomi Murray mengenai sistem kebutuhan dan dilanjutkan dengan pemngembangan TAT untuk mengetahui gambaran motivasi seseorang. Murai mendefinisikan n-ach sebagai kebutuhan untuk menyelesaikan sesuatu yang sulit, menguasai sesuatu dengan cepat dan mandiri, menyelesaikan permasalahan dan mencapai standar yang tinggi, menantang diri sendiri, bersaing dan mengungguli orang lain, mengembangkan penguasaan atas objek fisik, kemanusiaan, dan ide, serta melakukan semua hal tersebut sebagai kebanggaan, dengan latihan-latihan yang baik (Hall dan Lindsay, 1978).

Berdasarkan pada definisi tersebut maka tingginya kebutuhan berprestasi ditunjukkan degan usaha untuk selalu menyelesaikan tugas yang sulit sekalipun dengan baik dan mandiri, menanggulangi kesulitan-kesulitan yang menanggulangi kesulitan-kesulitan yang menghalangi, mencapai standar yang tinggi, serta keberanian untuk melakukan persaingan. Dikatakan oleh McClelland bahwa individu dengan kebutuhan berprestasi tinggi akan lebih memilih tugas-tuga dengan tingkat kesulitan moderat, karena tugas tersebut memiliki unsur menantang kemampuan dan masih dalam batas-batas kemampuan untuk dapat dikerjakan oleh seseorang. Sebaliknya individu yang memiliki $\mathrm{n}$-ach lebih rendah memilih tugas dengan kesulitan tinggi atau rendah sekali, Hal ini terjadi karena mereka tidak menyukai situasi dimana adanya tantangan dan ancaman akan kemampuan mereka. Perbedaan ni juga terlihat dalam strategi pemecahan masalah . Individu dengan $\mathrm{n}$-ach tinggi memiliki strategi pemecahan masalah yang mendukung usahanya dalam mencapai hasil yang diinginkan. Sebaliknya individu dengan nach rendah tidak memiliki strategi dalam pemecahan masalahnya, serta cenderung mudah putus asa dalam menghadapi kesulitan. McClelland (1987) mengatakan bahwa motivasi berprestasi dipengaruhi oleh dua faktor yaitu faktor intrinsik meliputi: Kemungkinan untuk sukses, ketakutan akan kegagalan, value, self-efficacy, serta usia, pangolin dan jenis kelamin. Sementara faktor eksternal meliputi lingkungan sekolah, keluarga serta teman.

\section{Prestasi Akademik Mahasiswa}

Prestasi merupakan hasil yang dicapai seseorang ketika mengerjakan tugas atau kegiatan tertentu. Tu'u (dalam Nurhayati, 2009) menjelaskan , bahwa prestasi akademik merupakan hasil belajar siswa yang diperoleh dari kegiatan pembelajaran di sekolah atau perguruan tinggi yang melihat pada aspek kognitif dan prestasi akademik ini umumnya ditentukan melalui pengukuran dan penilaian. Aspek kognitif inilah yang paling sering dinilai dan diukur oleh para pengajar di sekolah karena berkaitan dengan kemampuan dan kapabilitas siswa dalam menguasai sisi bahan pengajaran yang telah dipelajari sebelumnya (Qudsi, et al, 2011).

Banyak hal yang berpengaruh pada prestasi akademik siswa yang mengikuti dan Eller (1999) menyatakan untuk dapat menaikkan prestasi akademik siswa maka dibutuhkan hal0hal yang berfokus pada aspek-aspek dalam pembelajaran kognitif pada siswa, yakni: (1) mengembangkan keterampilan konseptual, (2) memaksimalkan skema dan transfer keterampilan dalam pembelajaran, (3) meningkatkan motivasi siswa, (4) menanamkan kepercayaan diri pada siswa, (5) mampu menantang siswa (challenging), (6) mengidentifikasi gaya belajar mahasiswa tiap-tiap siswa, dan (7) mengembangkan keterampilan berpikir yang baik (Qudsi, et al, 2011).

Sejumlah studi telah dilakukan untuk mengidentifikasi faktor-faktor penyebab prestasi 
akademik sejumlah lembaga di seluruh dunia. Sebagian besar dari studi ini berfokus pada tiga elemen yaitu, orang tua, dosen dan mahasiswa (Diaz, 2003).

\section{Metode Penelitian}

\section{A. Jenis Penelitian}

Jenis penelitian yang digunakan adalah penelitian survei. Penelitian ini adalah penelitian eksplanatori yang bermaksud untuk memberikan tiap instrumen yang dapat berupa pernyataan atau pertanyaan. penjelasan hubungan kausalitas antar variabel melalui pengujian hipotesis sekaligus melakukan eksplanasi. Sehingga dalam penelitian ini metode eksplanatori digunakan untuk mengetahui hubungan kausal antara variabelvariabel faktor psikologis yang terdiri dari Variabel Motivasi belajar (X1), dan Variabel Komitmen Organisasional (X2), terhadap prestasi mahasiswa (Y).

\section{B. Lokasi Penelitian}

Penelitian ini dilakukan pada Universitas Raharja Tangerang, Jl. Jenderal Sudirman, Tangerang. Lokasi ini dipilih berdasarkan pertimbangan peneliti bahwa universitas tersebut berupaya meningkatkan motivasi belajar dan komitmen organisasional. Pendidikan dan pengajaran adalah suatu proses yang sadar tujuan. Tujuan dapat diartikan sebagai suatu usaha untuk memberikan rumusan hasil yang diharapkan siswa setelah melaksanakan pengalaman belajar (Sardiman, 2004). Tercapai tidaknya tujuan pengajaran salah satunya adalah terlihat dari prestasi belajar yang diraih mahasiswa. Dengan prestasi yang tinggi, para mahasiswa mempunyai indikasi berpengetahuan yang baik.

Salah satu faktor yang mempengaruhi prestasi siswa adalah motivasi. Dengan adanya motivasi, siswa akan belajar lebih keras, ulet, tekun dan memiliki dan memiliki konsentrasi penuh dalam proses belajar pembelajaran. Dorongan motivasi dalam belajar merupakan salah satu hal yang perlu dibangkitkan dalam upaya pembelajaran di sekolah.

Penelitian Wasty Soemanto (2003) menyebutkan, pengenalan seseorang terhadap prestasi belajarnya adalah penting, karena dengan mengetahui hasil-hasil yang sudah dicapai maka siswa akan lebih berusaha meningkatkan prestasi belajarnya. Dengan demikian peningkatan prestasi belajar dapat lebih optimal karena siswa tersebut merasa termotivasi untuk meningkatkan prestasi belajar dapat lebih optimal karena mahasiswa tersebut merasa termotivasi untuk meningkatkan prestasi belajar yang telah diraih sebelumnya.

Biggs dan Telfer (dalam Dimyati dan Mudjiono, 2006) mengungkapkan motivasi belajar siswa dapat menjadi lemah. Lemahnya motivasi atau tiadanya motivasi belajar akan melemahkan kegiatan, sehingga mutu prestasi belajar akan rendah. Oleh karena itu, mutu prestasi belajar pada siswa perlu diperkuat terus-menerus. Dengan tujuan agar siswa memiliki motivasi belajar yang kuat, sehingga prestasi belajar yang diraihnya dapat optimal. Motivasi belajar yang dimiliki siswa dalam setiap kegiatan pembelajaran sangat berperan untuk meningkatkan prestasi belajar siswa dalam mata pelajaran tertentu (Nashar, 2004:11).

\section{Konsep, Variabel, Definisi Operasional dan Skala Pengukuran}

\section{Konsep}

a. Konsep Motivasi

Motivasi merupakan kondisi atau energi yang menggerakkan diri mahasiswa yang terarah atau tertuju untuk mencapai tujuan organisasi perusahaan.

b. Konsep Komitmen

Keinginan mahasiswa untuk tetap mempertahankan keanggotaan dirinya dalam organisasi dan bersedia melakukan usaha maksimal untuk mencapai tujuan organisasi. 
c. Konsep prestasi

prestasi adalah hasil yang dicapai mahasiswa dalam menyelesaikan pembelajarannya baik secara kuantitas, kualitas, dan sesuai dengan standar waktu.

\section{Variabel}

Adapun dalam penelitian ini variabel bebas adalah motivasi belajar (X1) dan komitmen organisasional $\left(\mathrm{X}_{2}\right)$, dan yang menjadi variabel terikat adalah prestasi mahasiswa (Y).

\section{Definisi Operasional}

Definisi operasional merupakan semacam petunjuk pelaksanaan bagaimana caranya mengukur suatu variabel sehingga dapat menentukan apakah prosedur pengukuran yang sama akan dilakukan atau diperlukan diperlukan prosedur pengukuran yang baru.

\section{Skala Pengukuran}

Penelitian ini menggunakan pengukuran skala likert Dalam skala Likert, variabel yang akan diukur dijabarkan ke dalam beberapa indikator variabel yang kemudian dari indikator tersebut disusun item-item

\section{Populasi dan Sampel}

Populasi pada penelitian ini adalah mahasiswa Universitas Raharja Tangerang. Adapun jumlah seluruh mahasiswa yang terdapat di Universitas Raharja adalah sebanyak 800 mahasiswa. Universitas Raharja. Sampel ditentukan sebanyak 89 mahasiswa yang diperoleh dari hasil perhitungan dengan menggunakan rumus Slovin.

\section{E. Uji Instrumen}

Pada uji validitas diketahui hasil penelitian valid dikarenakan korelasi tiap faktor positif dan besarnya 0,3 keatas, maka dapat dinyatakan item pertanyaan tersebut valid. Sedangkan pada uji reliabilitas instrumen dapat dikatakan andal (reliabel) bila memiliki koefisien keandalan reliabilitas sebesar 0,6 atau lebih.

\section{F. Pengumpulan Data}

Menurut Hasan (2002:83) "Pengumpulan data adalah pencatatan peristiwa-peristiwa, hal-hal, keterangan-keterangan dari sebagian karakteristik karakteristik atau seluruh elemen populasi yang akan menunjang atau mendukung penelitian".

Teknik analisis data yang digunakan dalam penelitian ini adalah linier garis regresi karena penelitian ini dirancang untuk melihat apakah faktor motivasi dan komitmen organisasi yang merupakan variabel bebas mempunyai pengaruh terhadap prestasi mahasiswa sebagai variabel terikatnya.

\section{G. Metode Analisis Data}

Metode analisis yang digunakan dalam penelitian ini adalah analisis deskriptif dan analisis inferensial. Sedangkan analisis inferensial yang digunakan dalam penelitian ini yaitu uji regresi linier berganda dan uji hipotesis.

\section{Hasil Dan Pembahasan}

\section{Hasil Analisis Regresi Linier Berganda}

Berdasarkan hasil pengolahan data menggunakan google form didapatkan ringkasan berikut :

Data chart Jenis kelamin

55.6\% Laki-laki, 44.4\% Perempuan

Sumber : Data primer (diolah) 2021 


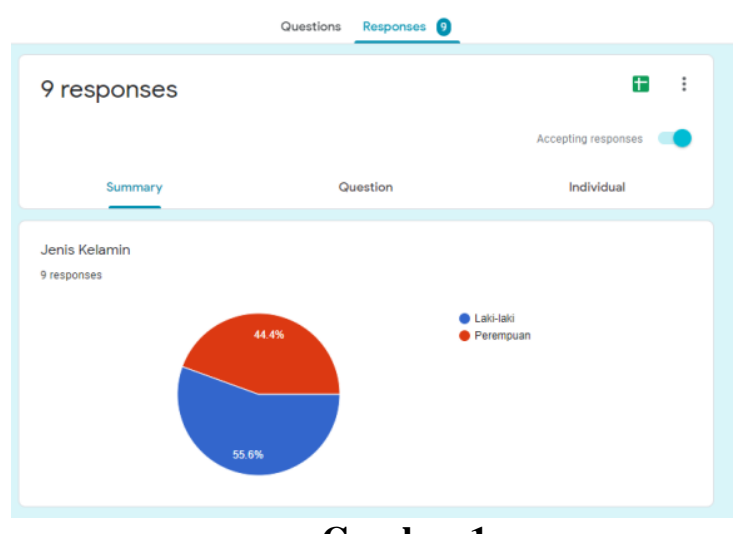

\section{Gambar 1}

\section{Data chart Umur}

$11.1 \%$ adalah 19 tahun, $55.1 \%$ adalah 20 tahun, $22,2 \%$ adalah 22 tahun. Sumber : Data primer (diolah) 2021

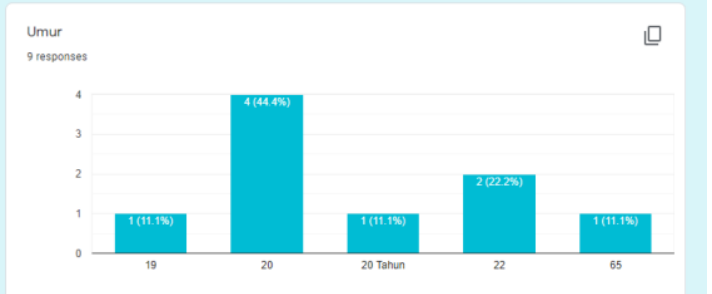

Gambar 2

Data chart apa yang membuat anda termotivasi $88.9 \%$ Suasana yang baik, $11.1 \%$ Kenyamanan Sumber : Data primer (diolah) 2021

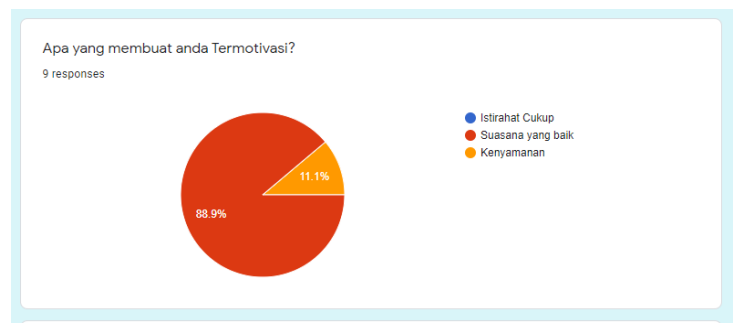

Gambar 3

Data chart apa pengaruh ketika anda termotivasi

55.6\% Keinginan kuat untuk berhasil, 22.2\% Memberi energi positif, $11.1 \%$ menjadi sumber semangat, $11.1 \%$ Membantu melawan rasa takut Sumber : Data primer (diolah) 2021

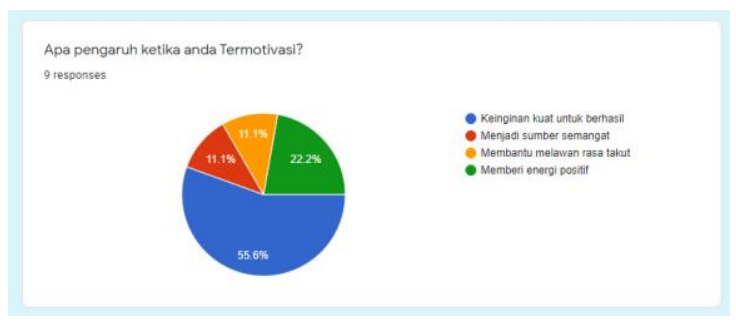

Gambar 4 
Data chart apa yang membuat anda semangat berorganisasi

87.5\% Dapat melakukan kebaikan, $12.5 \%$ Mendapatkan apresiasi

Sumber : Data primer (diolah) 2021

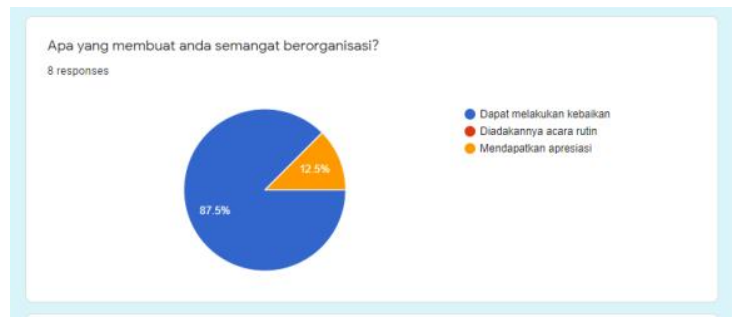

Gambar 5

Data chart apa yang membuat anda ingin tahu akan sebuah organisasi

66.7\% Memberikan manfaat, 22.2\% Membantu lebih konsisten 11.1\% Menjadi sumber semangat

Sumber : Data primer (diolah) 2021

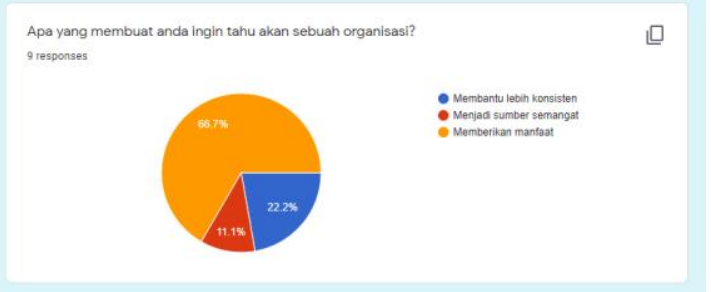

\section{Gambar 6}

\section{Data chart apa pengaruh ketika anda bersemangat}

55.6\% Menambah rasa ingin tahu dan inisiatif, 22.2\% Menyelesaikan pekerjaan dengan lebih mudah

$22.2 \%$ Beban kerja yang berat akan terasa lebih ringan

Sumber : Data primer (diolah) 2021

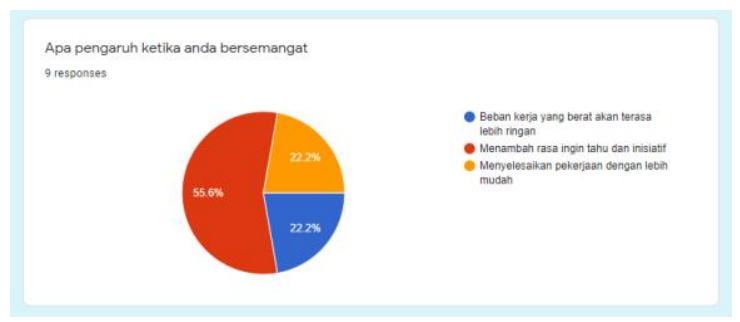

Gambar 7

\section{Pembahasan Hasil Penelitian}

Berdasarkan hasil uji simultan dapat diputuskan bahwa motivasi belajar akan diikuti dengan semakin tingginya semangat mahasiswa. Hal ini dikarenakan motivasi belajar merupakan variabel yang paling banyak berpengaruh terhadap meningkatnya prestasi mahasiswa.

\section{Kesimpulan}

Berdasarkan hasil penelitian yang telah dilakukan bahwa motivasi belajar dapat menumbuhkan semangat berorganisasi dan meningkatkan prestasi Mahasiswa. 
5. Saran

Bagi kompartemen Universitas Raharja tangerang sebaiknya dapat mempertahankan dan lebih memperhatikan lagi untuk memotivasi mahasiswa dan menjaga komitmen organisasional mahasiswa, karena berdasarkan penelitian tingginya motivasi belajar dan komitmen organisasional dapat memberikan dorongan kepada mahasiswa untuk meningkatkan prestasinya. Harapannya kompartemen Universitas Raharja Tangerang dapat menentukan kebijakan guna meningkatkan prestasi mahasiswa.

\section{Daftar Pustaka}

Enggar Dwi Jatmiko. (2014). Motivasi Berprestasi Pada Mahasiswa Berprestasi Dari Keluarga Tidak Mampu Secara Ekonomi Universitas Airlangga Vol. 3, No. 01, April 2014, 3, 1-7.

Ghullam Hamdu. (2015). Pengaruh Motivasi Belajar Siswa Terhadap Prestasi Belajar IPA di Sekolah Dasar Kelas IV SDN Tarumanagara Vol. 12, No. 1, April 2011, 12, 90-96.

Ratna Haryani M.M.W Tairas. (2015). Pengaruh Motivasi Kerja dan Komitmen Organisasional Terhadap Kinerja Karyawan Kompartemen Pabrik II PT. Petrokimia Gresik Vol. 21, No. 1, 2015, 21, 30-36.

Prapdopo. (2016). Analisis Beberapa Faktor yang Mempengaruhi Prestasi Akademik Mahasiswa Politeknik Negeri Samarinda Vol. 12, No. 1, 2016, 12, 3267-2373.

Tarida Marlin Surya Manurung. (2017). Pengaruh Motivasi dan Perilaku Belajar Terhadap Prestasi Akademik Mahasiswa STIE Kesatuan Jl.Ranggagading Bogor Vol. 1, No. 1, 2017, 1, 17-26.

Muhammad Taufik Daniel Hasibuan. (2020). Hubungan Motivasi belajar Terhadap Prestasi Akademik Pada Mahasiswa Yang Menjalani Pembelajaran Daring Selama Pandemi Covid-19 STIKes Murni Teguh Vol. 3, No. 2, November 2020, 21, 387-393.

Safitri Linawati. (2020). Prediksi Prestasi Akademik Mahasiswa Menggunakan Algoritma Random Forest Dan C4.5 Universitas Bina Sarana Informatika Vol. 8, No. 1, Juni 2020, 21, $47-52$.

Nasrah, A Muafiah. (2020). Pengaruh Motivasi Kerja dan Komitmen Organisasional Terhadap Kinerja Karyawan Kompartemen Pabrik II PT. Petrokimia Gresik Vol. 3, No. 2, Oktober 2020, 2, 207-213.

Muhammad Anas dan Farida Aryani. (2014). Motivasi Belajar Mahasiswa Universitas Negeri Makassar Vol. 16, No. 1, Juni 2014, 1, 41-46.

Budiman Tampubolon. (2020). Motivasi Belajar Dan Tingkat Belajar Mandiri Dalam Kaitannya Dengan Prestasi Belajar Mahasiswa Universitas Tanjungpura, Pontianak, Indonesia Vol. 5, No. 2, September 2020, 2, 34-41. 